Dept. Poultry Diseases

Fac. Vet. Med. Assiut University

\title{
PARAMYXOVIRUS INFECTION IN PIGEONS
}

(With 3 Tables and 2 Figures)

By

\section{R.S. IBRAHIM; T.Y. ABDEL-MOTELIB and M.S. ABDEL-HAFEZ *}

*Poultry production farms, Fac. of Agriculture, Assiut University (Received at 11/12/2004)

\section{عدوى فيروس الباراميكسو فى الحمام}

رجب سبي ابراهيم ، طلبه بيونس عبل المطلب ، محمد شاكر عبل الحافظ

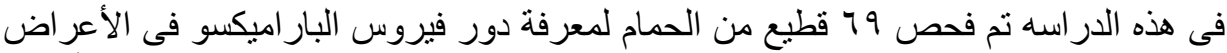

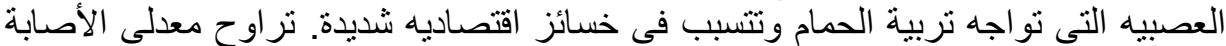

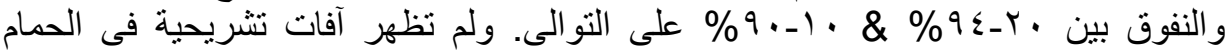

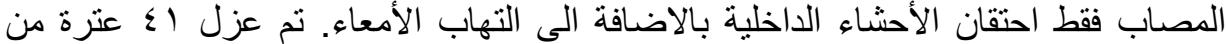

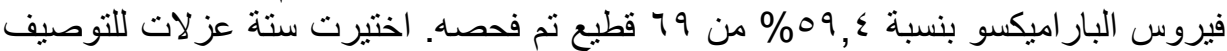

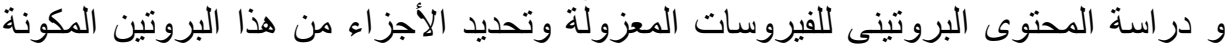

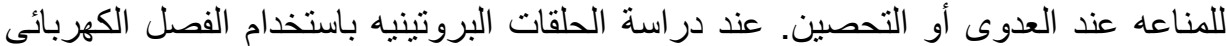

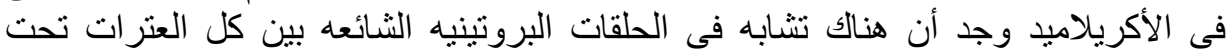

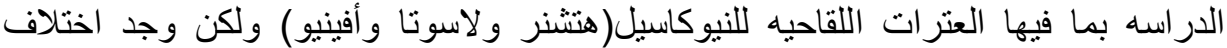

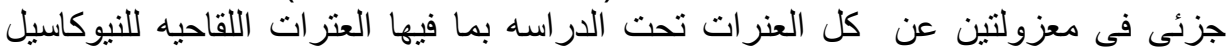

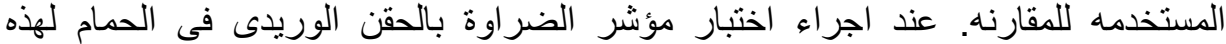

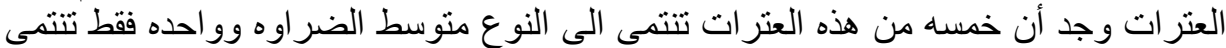

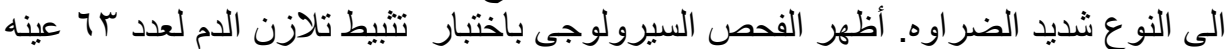

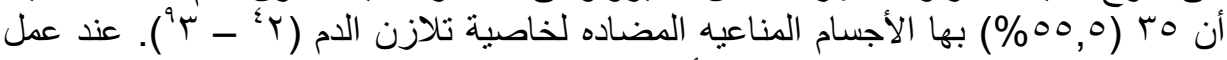

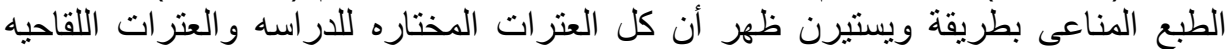

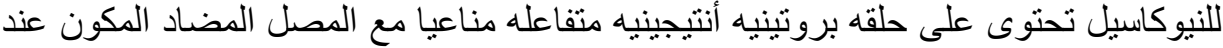

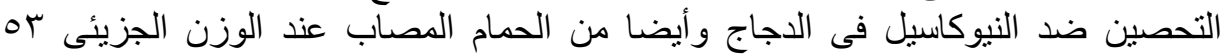

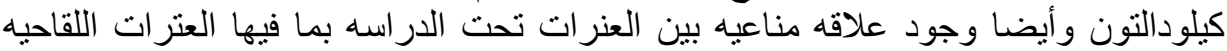

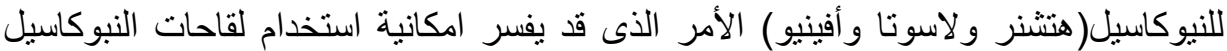

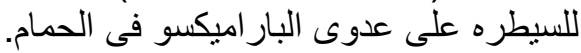

\section{SUMMARY}

This study investigated 69 pigeon flocks for the role of Paramyxovirus (PMV) in serious problem of nervous signs facing both loft and individual raising pigeons in Upper Egypt resulting in severe economic 
losses. The morbidity and mortality rates in the infected pigeons were $20-94 \%$ and $10-90 \%$ respectively. No pathognomonic lesions were noticed in infected pigeons far from congestion of parenchymatous organs and enteritis. Forty-one strains of PMV could be isolated (59.4\%) from 69 examined flocks. Six isolates were subjected for further characterization by SDS-PAGE and western blot analysis. Common polypeptide pattern was clear among the selected strains in SDS-PAGE but two isolates of them differed partially from the others and ND vaccinal strains, suggesting their relatedness to pigeon PMV. The intravenous pathogenicity index (IVPI) of the selected strains characterized 5 of them as mesogenic strains and one as velogenic strain. Serological survey of 63 serum samples displayed 35 (55.6\%) possess haemagglutination inhibiting (HI) antibodies with HI titers $2^{4}-2^{9}$. All the selected and ND vaccinal strains expressed a very major and highly reactive immunogenic epitope at $53 \mathrm{Kda}$, moreover there were close immunogenic relationship among pigeon PMV and ND vaccinal strains, the matter which may answer the question why we use ND vaccines for controlling PMV infection in pigeon.

Key words: Pigeon, paramyxovirus, HI, SDS-PAGE, Western blotting Pathogenicity, ND

\section{INTRODUCTION}

Pigeon are popular in most countries of the world; in Egypt most of the villagers raise pigeons mainly for meat production as well as for racing and show, in addition to the widely distributed pigeon lofts allover country. Pigeons also were used for biological and medical research where 70,000 pigeons are raised annually in United States. No doubt that nervous signs in pigeons represent one of the most important problems in Egypt in the last few years. Many etiological agents are involved in such problem as PMV-1, Herpes virus, Rabies virus and listeriosis (Webers et al., 1995) as well as chlamydiosis and paratyphoid. PPMV-1 infection in pigeons characterized by sudden onset, rapid spread with high morbidity and mortality of $100 \%$ and $80 \%$ respectively (Eisa and Omer, 1984), gradual decline in egg production with infertile eggs also reported (Povazsan, et al. 1984). Little work has been done for studying the virulence, SDS-PAGE of whole viral proteins and immunoblot analysis of PPMV-1 in Egypt, so the present work was designed to study the forementioned points in addition to studying the distribution of infection at area of Upper Egypt. 


\section{MATERIALS and METHODS}

\section{Birds and samples:}

One hundred and forty eight pigeons showing nervous signs represent 69 pigeon sources from both individual rearing and pigeon lofts were examined for signs and lesions, isolation and identification of causative virus. Pooled samples were collected from brain, liver, spleen, lung and kidney of each clinically affected bird.

\section{Isolation and identification:}

Bacteria free suspension from prepared sample was inoculated into allantoic cavity of 9-11-day-old embryonating chicken eggs, incubated at $37^{\circ} \mathrm{C}$ and examined twice daily for 7 days. Allantoic fluids were collected aseptically for viral identification.

\section{Haemagglutination (HA):}

All isolates were tested for HA character as well as determination of HA units using pigeon or chicken RBCs.

Sodium dodecyl sulphate polyacrylamide gel electrophoresis (SDSPAGE):

Six chicken embryo-propagated PPMV-1 isolates as well as three vaccinal strains of ND (Lasota, Hichner B1 and Avinew) were used for SDS-PAGE. The allantoic fluids of embryo-grown isolates and vaccinal strains were harvested and were cleared by centrifugation at $3000 \mathrm{rpm}$ for 20 minutes. The viruses were pelleted by centrifugation at 16,000 rpm for 1.5 hours in cooling centrifuge. The pellet was resuspended in $0.01 \mathrm{M}$ Tris- $\mathrm{HCl}$ buffer, $\mathrm{PH}$ 7.2. Centrifugation was done again at the same conditions mentioned formerly. The viral pellets were resuspended 1:1 weight per volume (W/V) in $2 \mathrm{X}$ sample buffer consisting of $0.5 \mathrm{M}$ Tris-HCl, glycerol, $10 \%$ SDS, 2-B-mercaptoethanol and $0.05 \%$ bromophenol blue and then placed in boiling water bath for 10 minutes. The final preparations were kept at -34C until use, (Shapiro and Maizel, 1969 and Alexander and Collins, 1981). Electrophoresis was carried out using vertical gel system (Bio-Rad). Polyacrylamide gel was prepared by the method of Laemmli (1970) using 4\% stacking gel (30 V for 45 minutes) and $10 \%$ separating gel (100 V for 2 hours). Running buffer used was consisted of 1.5 Tris, 7.2\% glycine and 0.5\% SDS (PH 8.3). Two gels were prepared; one used for staining while the other used for western blotting as unstained gel. Staining was done for 2 hours using $0.1 \%$ coomassie brilliant blue R-250 (Pharmacia, LKB Biotechnology, Uppsala, Sweden) in fixative solution. Destaining was performed with $40 \%$ methanol and $10 \%$ acetic acid until clear background was obtained. 
Approximate molecular weights were determined by comparing mobility pattern of samples with that of prestained molecular weight protein standard marker (Sigma, St. Luis); (180. 116, 84, 58, 48, 36.5, and 26.6 Kda molecular weight.

Serological monitoring:

Sixty-three serum samples of diseased pigeons were examined to detect antibodies to PPMV-1 based on haemagglutination inhibition reaction (HI).

\section{Intravenous pathogenicity index (IVPI):}

Intravenous pathogenicity index (IVPI) was carried out for six selected isolates of PMV-1 by I.V. inoculation of the virus derived from freshly infective allantoic fluids into ten 6-week-old pigeon free from PMV infection, each bird was examined daily for a period of 10 days and scored for assessment of virulence.

\section{Immunoblotting:}

This technique was performed according to Towbin et al., (1979) to determine the common immunogenic determinants shared in PMVs as well as the antigenic diversions among different isolates and ND vaccinal strains. Unstained SDS-PAGE was transferred to the supported nitrocellulose membrane $0.45 \mathrm{Um}$ (Bio-Rad) using semidry transblotting (Pharmacia). Three sheets of absorbent paper with the same dimensions of gel size were soaked in transfer buffer ( $48 \mathrm{mM}$ Tris base, $39 \mathrm{mM}$ glycine, $0.037 \%$ SDS vol./vol., 20\% methanol and distilled water). The gel was placed exactly on filter papers (3 layers), soaked nitrocellulose was then placed and covered with soaked layers of absorbent paper. Electrophoresis was carried out at $2 \mathrm{~mA} / \mathrm{cm}^{2}$ for one hour. The nitrocellulose membrane after assembling was stained by Ponceu stain for orientation, and then destained by distilled water. Blocking was done using PBS PH 7.2 containing $2 \%$ bovine serum albumin (BSA) at $4 \mathrm{C}$ overnight. Washing was done $3 \mathrm{X}$ using tris-buffered saline (PH 7.6) containing $0.05 \%$ tween 20 (TBS-Tween 20). Primary antibody (pooled antisera with high HA titers obtained from diseased pigeons), diluted in BSA-TBS-Tween 20 was added for 1 hour at room temperature with shaking. Washing was done $3 \mathrm{X}$, followed by introducing of Peroxidase labeled rabbit anti-chicken IgG diluted in BSA, TBS-Tween 20 at room temperature for 1 hour with shaking. Washing was done $5 \mathrm{X}$; the last wash was done using TBS without tween 20. The substrate used was 3,3 diaminobenzidine, tetrahydrochloride (DAB) (Sigma) as freshly prepared solution of $50 \mathrm{ml}$ Tris- $\mathrm{HCl}(\mathrm{PH} 7.5)$ containing $10 \mathrm{mg}$ of DAB and $25 \mu \mathrm{L}$ of $30 \% \mathrm{H}_{2} \mathrm{O}_{2}$. Substrate was added with shacking, and several 
washing in distilled water, the membrane kept to dry, stopped the reaction.

\section{Experimental infection:}

Sixty-nine squabs of 45 days old were proved free from PMV infection by $\mathrm{HI}$ test and divided into 7 groups, the first group (9 pigeons) was kept as non-infected control. Each of the other groups was subdivided into two groups ( 5 pigeons inoculated intranasalty with 0.1 $\mathrm{ml}$ of EID50 for each isolate and the 5 pigeons other was kept in contact with them). All birds were observed for a period of 30 days.

\section{RESULTS}

\section{Clinical signs and necropsy:}

The clinical signs of the naturally diseased birds were anorexia, depression, increased thirst, greenish watery diarrhea and nervous signs in the form of tremors of head and neck, torticollis, circling and paralysis of legs and wings. The morbidity and mortality were ranged from 20$94 \%$ and $10-90 \%$ respectively. There is no pathognomonic lesions were recorded, but only congestion of liver, spleen, pancreas and kidneys with enteritis sometimes noticed.

\section{Isolation and Identification:}

The inoculated embryos died between $2^{\text {nd }}$ and $8^{\text {th }}$ day of infection and showed curling and sometimes dwarfing with hemorrhages of the head and bodies in addition to presence of urates even mixed with allantoic fluids.

\section{Haemagglutination test:}

Forty-one isolates could be identified from 41 out of 69 pigeon flocks with $\log 2 \mathrm{HA}$ titers ranged from $2^{2}-2^{11}$. Data about the six selected isolates are listed in Table 1.

\section{SDS-PAGE:}

SDS-PAGE that displayed the common whole protein pattern of molecular weights 53,48 and $32 \mathrm{Kda}$ to all six tested isolates. One of these isolates was completely similar to ND lasota vaccine that possessed protein molecular weight of 128, 53, 48, 32, 23 and $18 \mathrm{Kda}$. Three isolates were similar to the other ND vaccinal strains (Hitchner B1 and Avinew) with protein molecular weights of 150, 56, 53, 48, 32, 23 and $18 \mathrm{Kda}$. Two isolates were differed partially from both of the other isolates and the vaccinal strains that may be special pigeon PMVs. (Fig.1). 


\section{Serological monitoring:}

Thirty-five out of 63 serum samples (55.6\%) showed haemagglutinating-inhibiting antibodies, with titers ranged from $2^{2}-2^{9}$. Data about the six selected isolates are listed in Table 1.

\section{Intravenous pathogenicity index:}

The intravenous pathogenicity index experiment for the six selected isolates revealed that five isolates belonged to mesogenic group while only one isolate belonged to velogenic group, results are illustrated in table (2).

\section{Immunoblotting:}

Immunoblott analysis of the six isolates and three vaccinal strains of NDV at the used dilution of antiserum and secondary antibody or rabbit anti-chicken IgG demonstrated a very major and highly reactive immunogenic epitope at $53 \mathrm{Kda}$ in all six isolates and vaccinal strains. Furthermore three isolates expressed additional immunogenic band at 48 $\mathrm{Kda}$, while only one isolate expressed a third immunogenic determinant at $32 \mathrm{Kda}$ (Fig. 2).

\section{Experimental infection:}

Similar clinical signs and lesions to those recorded in natural infection were observed in intranasal and contact infected groups. The morbidity and mortality rate were $100 \%$ and $40-80 \%$ respectively. Successful reisolation of the virus was achieved, on the other hand control birds showed no signs and lesions or positive reisolation of the virus (Table 3).

\section{DISCUSSION}

The role of pigeons in the transmission of diseases to both humans and domestic species of birds has been well documented by several authors (Weber et al., 1979; Alexander et al., 1985 and Orlandella et al., 1992). This study aimed to provide information on PPMV-1 infection in pigeons in Upper Egypt. This work was carried out on 69 pigeon lofts representing 13285 birds.

Clinical signs of naturally infected pigeons were anorexia, depression, increased thirst, greenish watery diarrhea and nervous signs in the form of tremors of head and neck, torticollis, circling and paralysis of legs and wings. Similar clinical picture were described by Alexander et al., (1984), Povazsan et al., (1984), Barton et al., (1992), El-Sisi et al., (1995), and Zanetti et al., (2001).

The morbidity and mortality were ranged from $20-94 \%$ and $10-$ $90 \%$ respectively. Low morbidity and mortality were recorded in adult 
pigeons comparatively to the higher rates in young one, this is might explained by previous exposure to infection and subsequent possessing of antibodies. These results more or less agree with those observed by Weisman et al., (1984), Henrichs (1997) and Ren Zuyi et al., (1998).

There is no pathognomonic lesions were recorded, but only congestion of liver, spleen, pancreas and kidneys with enteritis sometimes noticed. Pearson et al., (1987), El-Mubarak et al., (1990) and Ibrahim et al., (2000) described similar necropsy findings.

Death of inoculated embryos was observed between $2^{\text {nd }}$ and $8^{\text {th }}$ day of infection. The dead embryos showed curling and sometimes dwarfing with hemorrhages of the head and bodies in addition to presence of urates with allantoic fluids. These results agreed with results of Beard and Hanson (1984).

Forty-one out of 69 pigeon sources with nervous signs were positive for PMV isolation with percentage of 59.4\%. The high HA titers agree with Biancifiori and Fioroini (1983) and Sambasivon et al., (2001), and disagree with those reported by King (1994). The isolates producing high HA titers $2^{7}-2^{11}$ were selected for further studies.

In present study, SDS-PAGE that displayed the common whole protein pattern of molecular weights 53,48 and $32 \mathrm{Kda}$ to all six tested isolates. One of these isolates was completely similar to ND lasota vaccine that possessed protein molecular weight of 128, 53, 48, 32, 23 and $18 \mathrm{Kda}$. Three isolates were similar to the other ND vaccinal strains (Hitchner B1 and Avinew) with protein molecular weights of 150, 56, 53, 48, 32, 23 and $18 \mathrm{Kda}$. Two isolates were differed partially from both of the other isolates and vaccinal strains that may be special pigeon PMVs. These results are partially supported by the findings of Walter et al., (1971) who found at least 5-6 proteins in PMV using SDS-PAGE. Four of the proteins found in each virus share common characters with nucleocapsid protein (56-61 Kda), a larger one (65-74 Kda), a smaller one $(53-56) \mathrm{Kda})$, and a major protein which is the smallest one in each virion (38-41 Kda). Moreover, Moore and Burke (1974) described 3 major proteins with molecular weights of 75,55 and $42 \mathrm{Kda}$ and minor proteins of 180, 110, 55, 53, 52, 51 and $49 \mathrm{Kda}$.

The method used in this study was done on whole polypeptides of isolated PMV (infected allantoic fluids) with high-speed centrifugation as simple and easy tool for such investigation. Such method was supported by Shapiro and Maizel (1969) and Sambasivan et al., (2001). 
Thirty-five out of 63 serum samples (55.6\%) showed HI antibodies against ND lasota vaccine, and ranged from $2^{4}-2^{9}$, nearly similar results were obtained by Schulte (1992) who reported 46.7\%, $2.5 \%$ and $0.5 \%$ PMV-1, PMV-2 and PMV-3 respectively.

Immunoblott analysis of the six isolates and three vaccinal strains of NDV at the used dilution of antiserum (1/200) and secondary antibody or rabbit anti-chicken $\operatorname{IgG}(1 / 2000)$ demonstrated a very major and highly reactive immunogenic epitope at $53 \mathrm{Kda}$ in all six isolates and three vaccinal strains. Furthermore three isolates expressed additional immunogenic band at $48 \mathrm{Kda}$, while only one isolate expressed a third immunogenic determinant at $32 \mathrm{Kda}$. Chambers and Samson (1980) observed 8-10 viral proteins in SDS-PAGE and western blotting on studying NDV polypeptides. Also Nishikawa et al., (1983) and Umino et al., (1990) studied the immunogenic proteins of NDV strains. Immunogenic proteins were studied by immunoblotting with homologous and heterologous antisera; the three viruses reacted evenly (Mishra et al., 2001).

Experimentally infected pigeons via $\mathrm{I} / \mathrm{N}$ and contact gave clinical signs similar to that noticed in naturally infected birds. All routes gave $100 \%$ morbidity but mortalities were $100 \%$ in case of $\mathrm{I} / \mathrm{N}$ exposure and ranged from $40-80 \%$ on contact exposure. The present results come in contrast with those reported by Alexander and Parsons (1984) where they found that $\mathrm{I} / \mathrm{N}$ infection did not produce nervous signs or death. On the other hands present results in case of $\mathrm{I} / \mathrm{N}$ infected pigeons more or less agreed with those of El-Mubarak et al., (1990) and El-Sisi et al., (1995). The high morbidity and mortality rates in experimentally infected pigeons may attribute to the highly virulent isolates caused severe losses in the field.

IVPI of six tested isolates were ranged from 1.08-to-1.72 and hence all of these isolates characterized as mesogenic strains and only one isolate as velogenic strain.

Based on this experiment it is concluded that a major polypeptide at $53 \mathrm{Kda}$ is a common antigenic site of PMV. Moreover, there are close immunogenic antigenic relationship among pigeon PMV isolates and vaccinal strains of NDV, the matter which may answer the question why we can use NDV vaccines for controlling infection in pigeons, but it is better to use autogenous vaccine prepared from PPMV isolates. 


\section{REFERENCES}

Alexander D.J. and Collins M.S. (1981): The structural polypeptides of avian paramyxoviruses. Archives of virology. 67: 309-323.

Alexander D.J. and Parsons G. (1984): Avian paramyxovirus type 1 infection of racing pigeons: 2 pathogenicity experiments in pigeons and chickens. Vet. Rec. 114 (19): 466-469.

Alexander D.J.; Russell P.H.; Parsons G.; Abu Elzein E.M.M.; Ballough A.; Cernik K.; Engstrom B.; Fevereiro M.; Fleury H. A.; Guittet M.; Kaleta E.F.; Kihm U.; Kosters J.; Lomniczi B.; Meister J.; Meulemans G.; Nerome K.; Petek M.; Pokomunski S.; Polten B.; Prip M.; Richter R.; Saghy E.; Samberg Y.; Spanoghe L. and Tumova B. (1985): Antigenic and biological characterization of avian paramyxovirus type 1 isolates from pigeons (an international collaborative study) Avian Pathology, 14: 365-376.

Alexander D.J.; Russell P.H. and Collins M.S.et (1984): Paramyxovirus type 1 infection of racing pigeons: 1 characterization of isolated viruses. Vet. Rec. 114, 444-446.

Barton J.T.; Bickford A.A.; Cooper G.L.; Charlton and Cardona C.J. (1992): Avian paramyxovirus type 1 infection in racing pigeons in California-1-Clinical signs, pathology and serology. Avian Diseases. 39, 463-468.

Beard C.W. and Hanson P.P. (1984): Newcastle Disease in M.S. Hofstad, H.J. Barns, B.W. Calnek, W.M. Reid, H.W. Yoder (eds). Diseases of Poultry, $8^{\text {th }}$ ed. Iowa State University Press, Ames, IA. pp. 452-470.

Biancifiori F. and Fioroini A. (1983): An occurrence of Newcastle disease in pigeons: Virological and serological studies on the isolates. Comp. Immun. Microbiol. Infect. Dis. 6(3): 247-252.

Chambers P. and Samson A.C.R. (1980): A new structural protein of Newcastle disease virus. J.General Virology. 50(1): 155-166.

Eisa M. and Omer E.A. (1984): A natural outbreak of Newcastle disease in pigeons in Sudan. Vet. Rec. 114, 297

El-Mubarak A.K.; Elzein E.E.E.A. and El-Gasim A.I.A. (1990): Note on the pathology of experimental infection of pigeons by the pigeon paramyxovirus-1 (PPMV-1) Revue-d'Elevage-et-deMedicine-veterinaire-des-pays-Tropicaux. 43: 4, 441-444. 
El-Sisi M.A.; Shakal M.; Aly A. and Hashem N.A. (1995): Pathogenicity of recent isolates of pigeon paramyxovirus in pigeons in Egypt. Vet. Med. J. Giza, 43: 2, 207-212.

Henrichs, S. (1997): Search for pathogens in dead racing pigeon's squabs, particularly reovirus and paramyxovirus. Vet. Bulletin, 67(4), abstract no. 1890.

Ibrahim, R.S.; Fatma A.; Moustafa and Mubarak M. (2000): Paramyxovirus infection in pigeons. Assiut Vet. Med. J., 44(87): 206-222.

King D.J. (1994): Avian paramyxovirus type 1 from pigeons: isolate characterization and pathogenicity after chicken or embryo passage of selected isolates. Avian Diseases, 40(3): 707-714.

Laemmli U.K. (1970): Cleavage of structural proteins during the assembly of the head of bacteriophage T4. Nature, 227: 680685.

Mishra S.; Kaleta J.M.; Verma K.C. and Mishra J.P. (2001): Comparison of protein profile of Newcastle disease isolated from different avian species. Indian J. of Animal Sciences. 71 (2): 88-91.

Moore N.F. and Burke D.C. (1974): Characterization of the structural proteins of different strains of Newcastle disease virus. J. General Virology. 25(2): 275-289.

Nishikawa K.; Isomura S.; Suzuki S.; Watanabe E.; Yamaguchi M.; Yoshida T. and Nagai Y. (1983): Monoclonal antibodies to HN glycoprotein of Newcastle disease virus. Biological characterization and use for strain comparisons. Virology, 130: 318-330.

Orlandella B.M.; Catanella N.; Foti M.; Leopizzi N.; Daidone A.; D'aura D. and Orlandella $V$. (1992): Rieserche sul ruolodel colombonella diffusione di agenti patogeni zoonosisi III: Le Salmonelle. Indagini nella citta di Messina. Acta Medica Veterinaria, 38, 123-146.

Pearson J.E.; Senne D.A.; Alexander D.J.; Taylor W.D.; Peterson L.A. and Russell P.H. (1987): Characterization of Newcastle disease virus (Avian paramyxovirus-1) isolated from pigeons. Avian Diseases, 31(1): 105-111.

Povazsan J.; Bitay Z.; Saghy E. and Meder M. (1984): Occurrence of an epidemic disease caused by paramyxovirus in Hungary in racing pigeon flocks. I. Clinical, pathological and 
epidemiological observation. Magyar allatorvosok lapja, 39(7): 205-208.

Ren Zuyi, Lu Xin HAO, ZHU Meng Dai, Hong Hong and Lao Wel Zhou (1998): Preliminary investigation of paramyxovirus-1 infection control in pigeons. Chinese Journal of Vet. Med., 24(12): 1112.

Sambasivan N.; Majee S.B. and Sherihar A.A. (2001): Protein profiles of field isolates and vaccinal strains of Newcastle disease virus. Indian J. of animal Science. 71(8): 1764-1765.

Schulte H. (1992): Serological investigation of antibodies to Herpes virus, Reo virus, TRT virus, Adeno virus and paramyxoviruses, 1,2 and 3 in German racing pigeons, and their relationship to clinical and pathological findings. Fachbereich Veterinarmedizin, Justus-Liebig-Universitat, Giessen, Germany, pp 112.

Shapiro P.L. and Maizel J.L. (1969): Molecular weight estimation of polypeptides by SDS-PAGE. Further data concerning resolving power and general consideration. Analytical Biology, 29: 505514.

Towbin H.T.; Stachelon T. and Gordon J. (1979): Electrophoretic transfer of proteins from polyacrylamide gels to nitrocellulose sheets: procedure and applications. Proc. Acad. Sci., U.S.A., 76: 4350-4354.

Umino Y.; Kohama T.; Sato T.A.; Sugiura A.; Klenk H.D. and Rott R. (1990): Monoclonal antibodies to three structural proteins of Newcastle disease virus: biological characterization with particular reference to the conformational changes of envelope glycoproteins associated with proteolytic cleavage. J. of General Virology, 71: 1189-1197.

Walter E. Mountcastle; Richard W. Compans and Puenell W. Choppin (1971): Proreins and glycoproteins of paramyxoviruses. A comparison of Simian virus S, Newcastle disease virus and Sendai virus. J. of virology, 7(1): 47-52.

Weber A.; Potel J. and Schafer-Schmidt R. (1995): Occurrence of Listeria monocytogenes in fecal samples of pigeons. Berliner and Munchener Tierarztliche Wochenschrift, 108 (1): 26-27.

Weber J.; Haag D. and Durrer H. (1979): Interaction between humans and pigeons. Anthrozoos, 1, 55-59. 
Weisman Y.; Aronovici A.; Malkinson M.; Shihmanter E. and Lipkind M. (1984): Isolation of paramyxoviruses from pigeons in Israel. Vet. Rec., 115 (23): 605.

Zanetti A.B.; Rosana Mattiello, Cesar Garbino, analia Kaloghlian, Maria Victoria Terrera, Juan Boviez, Eduardo Palma, Elisa Carrillo and Analia Berinstein (2001): Biological and molecular characterization of pigeon paramyxovirus type 1 isolate found in Argentina. Avian Diseases, 45: 547-571.

Table.1: Epidemiology and titeration of six selected pigeon isolates of PMV

\begin{tabular}{ccccccc}
\hline $\begin{array}{c}\text { Isolate } \\
\text { No. }\end{array}$ & $\begin{array}{c}\text { Age in } \\
\text { month }\end{array}$ & $\begin{array}{c}\text { Morbidity } \\
\%\end{array}$ & $\begin{array}{c}\text { Mortality } \\
\%\end{array}$ & $\begin{array}{c}\mathrm{HA} \\
\text { titer }\end{array}$ & $\begin{array}{c}\mathrm{HI} \\
\text { titer }\end{array}$ & EID50\%/ml \\
\hline 1 & 12 & 80 & 70 & $2^{9}$ & $2^{6}$ & $10^{-6}$ \\
2 & 24 & 90 & 80 & $2^{7}$ & $2^{8}$ & $10^{-6.7}$ \\
3 & 9 & 62 & 42 & $2^{9}$ & $2^{6}$ & $10^{-7}$ \\
4 & 6 & 92 & 80 & $2^{7}$ & $2^{5}$ & $10^{-4.8}$ \\
5 & 12 & 89 & 74 & $2^{11}$ & $2^{6}$ & $10^{-6.7}$ \\
6 & 6 & 93 & 73 & $2^{11}$ & $2^{2}$ & $10^{-6}$ \\
\hline
\end{tabular}


Fig 1: SDS-PAGE profile ot total viral protein of PPMV isolates and three ND vaccinal strains; stained with coomassie blue stain. M (prestained protein molecular weight marker) showing molecular weights of 180 , 116, 84, 58, 48, 36.5, 26.6 KD. Lanes 1-6 (PPMV isolates). Lanes 7-9 (ND vaccinal strains; Lasota, Hitchner, Avinew).

Fig 2: Western blotting of PPMV isolates and three ND vaccinal strains. M (prestained protein molecular weight marker) showing molecular weights of 180, 116, 84, 58, 48, 36.5, $26.6 \mathrm{KD}$. Lanes 1-6 (PPMV isolates). Lanes 7-9 (ND vaccinal strains; Lasota, Hitchner, Avinew). Thick arrow (Highly reactive immunogenic epitope at $53 \mathrm{KD}$ expressed in all PPMV-1 isolates and ND vaccinal strains). Lanes 3, 4 and 5 expressed additional band at $48 \mathrm{KD}$. Lane 5 expressed a third immunogenic determinant at $32 \mathrm{KD}$. 
Table.1: Epidemiology and titeration of six selected pigeon isolates of PMV

\begin{tabular}{ccccccc}
\hline $\begin{array}{c}\text { Isolate } \\
\text { No. }\end{array}$ & $\begin{array}{c}\text { Age in } \\
\text { month }\end{array}$ & $\begin{array}{c}\text { Morbidity } \\
\%\end{array}$ & $\begin{array}{c}\text { Mortality } \\
\%\end{array}$ & $\begin{array}{c}\text { HA } \\
\text { titer }\end{array}$ & $\begin{array}{c}\text { HI } \\
\text { titer }\end{array}$ & EID50\%/ml \\
\hline 1 & 12 & 80 & 70 & $2^{9}$ & $2^{6}$ & $10^{-6}$ \\
2 & 24 & 90 & 80 & $2^{7}$ & $2^{8}$ & $10^{-6.7}$ \\
3 & 9 & 62 & 42 & $2^{9}$ & $2^{6}$ & $10^{-7}$ \\
4 & 6 & 92 & 80 & $2^{7}$ & $2^{5}$ & $10^{-4.8}$ \\
5 & 12 & 89 & 74 & $2^{11}$ & $2^{6}$ & $10^{-6.7}$ \\
6 & 6 & 93 & 73 & $2^{11}$ & $2^{2}$ & $10^{-6}$ \\
\hline
\end{tabular}

Table 3: Results of experimental infection of six selected PPMV isolates

\begin{tabular}{|c|c|c|c|c|c|c|c|}
\hline \multirow{2}{*}{$\begin{array}{c}\text { Isolate } \\
\text { No. }\end{array}$} & \multirow{2}{*}{$\begin{array}{l}\text { Route of } \\
\text { Infection }\end{array}$} & \multirow{2}{*}{$\begin{array}{c}\text { Incubation } \\
\text { Period }\end{array}$} & \multicolumn{2}{|c|}{ Signs } & \multicolumn{2}{|c|}{ Death } & \multirow[t]{2}{*}{ Course } \\
\hline & & & $\%$ & Days PI & $\%$ & Days PI & \\
\hline \multirow{2}{*}{1} & Intranasal & 9 & 100 & $8-14$ & 100 & $10-18$ & 18 \\
\hline & Contact & 14 & 100 & $14-25$ & 40 & $16-24$ & 30 \\
\hline \multirow{2}{*}{2} & Intranasal & 9 & 100 & $9-13$ & 100 & $11-22$ & 16 \\
\hline & Contact & 11 & 100 & $11-22$ & 80 & $12-28$ & 30 \\
\hline \multirow{2}{*}{3} & Intranasal & 6 & 100 & $6-16$ & 100 & $8-21$ & 21 \\
\hline & Contact & 17 & 100 & $17-25$ & 60 & $20-30$ & 30 \\
\hline \multirow{2}{*}{4} & Intranasal & 6 & 100 & $6-12$ & 100 & $9-16$ & 16 \\
\hline & Contact & 14 & 100 & $14-21$ & 60 & $19-30$ & 30 \\
\hline \multirow{2}{*}{5} & Intranasal & 11 & 100 & $11-14$ & 100 & $17-23$ & 17 \\
\hline & Contact & 17 & 100 & $17-23$ & 80 & $20-30$ & 30 \\
\hline \multirow{2}{*}{6} & Intranasal & 6 & 100 & $6-9$ & 100 & $8-13$ & 13 \\
\hline & Contact & 16 & 100 & $16-22$ & 80 & $20-30$ & 30 \\
\hline
\end{tabular}




\section{Table (3): Showing Intravenous Pathogenicity Indeces (IVPI) of six selected pigeon PMV isolates}

\begin{tabular}{|c|c|c|c|c|c|c|c|c|c|c|c|c|c|c|c|}
\hline \multirow{2}{*}{$\begin{array}{l}\text { solate } \\
\text { No. }\end{array}$} & \multirow{2}{*}{$\begin{array}{l}\text { No. of } \\
\text { Birds }\end{array}$} & \multicolumn{10}{|c|}{ Period of obs ervation in days } & \multirow{2}{*}{ Sum } & \multirow{2}{*}{ Factor } & \multirow{2}{*}{ Total } & \multirow{2}{*}{ IVPI } \\
\hline & & 1 & 2 & 3 & 4 & 5 & 6 & 7 & 8 & 9 & 10 & & & & \\
\hline \multirow{4}{*}{1} & Dead & - & - & - & - & - & 4 & 4 & 4 & 6 & 8 & 26 & 4 & 104 & \multirow{4}{*}{$\begin{array}{c}1.28 \\
\text { Mesogenic }\end{array}$} \\
\hline & Diseased & - & - & - & - & 4 & - & - & 2 & 4 & 2 & 12 & 2 & 24 & \\
\hline & Normal & 10 & 10 & 10 & 10 & 6 & 6 & 6 & 4 & - & - & 62 & 0 & 0 & \\
\hline & Total & & & & & & & & & & & 100 & & 128 & \\
\hline \multirow{4}{*}{2} & Dead & - & - & - & - & - & 2 & 2 & 2 & 6 & 6 & 18 & 4 & 72 & \multirow{4}{*}{$\begin{array}{c}1.08 \\
\text { Mesogenic }\end{array}$} \\
\hline & Diseased & - & - & - & - & 2 & 2 & 4 & 4 & 2 & 4 & 18 & 2 & 36 & \\
\hline & Normal & 10 & 10 & 10 & 10 & 8 & 6 & 4 & 4 & 2 & - & 64 & 0 & 0 & \\
\hline & Total & & & & & & & & & & & 100 & & 108 & \\
\hline \multirow{4}{*}{3} & Dead & - & - & - & - & - & 2 & 4 & 4 & 4 & 4 & 18 & 4 & 72 & \multirow{4}{*}{$\begin{array}{c}1.24 \\
\text { Mesogenic }\end{array}$} \\
\hline & Diseased & - & - & - & - & 6 & 4 & 2 & 4 & 4 & 6 & 26 & 2 & 52 & \\
\hline & Normal & 10 & 10 & 10 & 10 & 4 & 4 & 4 & 2 & 2 & - & 56 & 0 & 0 & \\
\hline & Total & & & & & & & & & & & 100 & & 124 & \\
\hline \multirow{4}{*}{4} & Dead & - & - & - & - & - & 2 & 2 & 6 & 8 & 8 & 26 & 4 & 104 & \multirow{4}{*}{$\begin{array}{c}1.40 \\
\text { Mesogenic }\end{array}$} \\
\hline & Diseased & - & - & - & - & 2 & 4 & 6 & 2 & 2 & 2 & 18 & 2 & 36 & \\
\hline & Normal & 10 & 10 & 10 & 10 & 8 & 4 & 2 & 2 & - & - & 56 & 0 & 0 & \\
\hline & Total & & & & & & & & & & & 100 & & 140 & \\
\hline \multirow{4}{*}{5} & Dead & - & - & - & - & - & 4 & 4 & 6 & 6 & 6 & 26 & 4 & 140 & \multirow{4}{*}{$\begin{array}{c}1.40 \\
\text { Mesogenic }\end{array}$} \\
\hline & Diseased & - & - & - & 4 & 4 & 2 & 2 & - & 2 & 4 & 18 & 2 & 36 & \\
\hline & Normal & 10 & 10 & 10 & 6 & 6 & 4 & 4 & 4 & 2 & - & 56 & 0 & 0 & \\
\hline & Total & & & & & & & & & & & 100 & & 140 & \\
\hline \multirow{4}{*}{6} & Dead & - & - & - & - & 2 & 2 & 2 & 4 & 10 & 10 & 30 & 4 & 120 & \multirow{4}{*}{$\begin{array}{c}1.72 \\
\text { Mesogenic }\end{array}$} \\
\hline & Diseased & - & - & - & 4 & 2 & 6 & 8 & 6 & - & - & 26 & 2 & 52 & \\
\hline & Normal & 10 & 10 & 10 & 6 & 6 & 2 & - & - & - & - & 44 & 0 & 0 & \\
\hline & Total & & & & & & & & & & & 100 & & 172 & \\
\hline
\end{tabular}


Table 2: Showing Intravenous Pathogenicity Indeces (IVPI) of six selected pigeon PMV isolates. 
Assiut Vet. Med. J. Vol. 51 No. 104 January 2005 